\title{
Zizyphus lotus (L.) Extracts as Prebiotics in the Aggregation and Adhesion of Probiotic and Inhibition of Pathologic Bacteria from Patients with Colorectal Cancer
}

\author{
Sara Ouldchikh ${ }^{\mathrm{a}^{*}}$, Aicha TirTouil ${ }^{\mathrm{a}}$, And Boumédiene Meddah ${ }^{\mathrm{a}}$ \\ ${ }^{\text {a }}$ Laboratory of Bioconversion, Microbiology Engineering and Health Safety, Faculty SNV, University of \\ Mascara-29000, Algeria \\ ${ }^{*}$ Corresponding author \\ s.ouldchikh@univ-mascara.dz \\ TEL: +2130779593614
}

Received: 22 July 2018; Published online: 18 April 2020

\begin{abstract}
The mucosal surfaces of the intestinal tract harbor a complex microbiota. Bacteria enter in contact with intestinal cells and bestow important nutritional, metabolic and protective functions which benefit the host. Various factors are able to alter the balances between different intestinal bacteria. Dysbiosis has been described in various pathologies and metabolic diseases in humans, such as cancer. Colorectal cancer pathology can benefit from gut microbial imbalance. Its overgrowth may lead to acute symptoms. An alternative strategy to restore this balance is the use of plant extracts which exhibit a prebiotic activity by stimulating probiotic bacteria and antimicrobial activity against pathogenic bacteria colonization. The present study aims to evaluate the in vitro antioxidant and antibacterial activity of phenolic extracts (Aqueous extract "AE" and Methanolic extract "ME") from Zizyphus lotus. It aims also to investigate the effect of this extract as a prebiotic on the aggregation of probiotic and inhibitory effects of pathogenic bacteria isolated from faeces of patients with colorectal cancer. Phytochemical analysis of different extracts from Zizyphus lotus by HPLC showed that all are rich in phenolic compounds (225.40 mgAGE/gDW for $\mathrm{AE}$ and $63.04 \mathrm{mgAGE} / \mathrm{gDW}$ for ME extracts). Moreover, all extracts showed an important antioxidant activity $(227 \mu \mathrm{g} / \mathrm{ml}$ for AE and $195 \mu \mathrm{g} / \mathrm{ml}$ for ME). These extracts also exhibited a significant prebiotic effect and antibacterial activity. Characterization of the in vitro effect of the aqueous extract showed that the percentage of autoaggregation and adhesion of probiotic and inhibitory effects of pathogenic bacteria increased in the presence of aqueous extracts.
\end{abstract}

Keywords: Zizyphus lotus(L.); Extracts; Colorectal cancer; Aggregation; Adhesion; Antimicrobial activity

\section{Introduction}

The human gut microbiota can be considered as a separate organ that has co-evolved with humans to achieve a symbiotic relationship leading to physiological homeostasis (Backhed, Ley, L Sonnenburg, Peterson \& I Gordon, 2005). A number of gastrointestinal disease states or disorders have been proposed to be associated with changes in the composition or function of gut microbiota. However, opportunistic and pathogenic infections can benefit from gut microbial imbalance. Their overgrowth may lead to acute symptoms. This is implicated in many digestive diseases (van Nimwegen et al., 2011) like inflammatory bowel diseases and colorectal cancer. Gut microbiota are an important factor associated with colorectal cancer (CRC), one of the 
most common malignant tumor types in the world (Azcarate-Peril, Sikes \& Bruno-Barcena, 2011). Each year, nearly one million new CRC cases are diagnosed worldwide and more than 500,000 deaths are reported (Jemal et al., 2011). It is the third most-diagnosed malignancy in the world according to the GLOBOCAN study (Parkin, Bray, Ferlay \& Pisani, 2001) and the second deadliest cancer after lung cancer in western countries. There is also emerging evidence that intestinal bacteria may play a role in the initiation of colon cancer through the production of carcinogenic chemicals (Rowland, 2009).

Recently, the use of probiotics, which are beneficial bacteria present in the intestine, is an alternative strategy to maintain the balance of the intestinal microbiota by the reduction of its pathogenic members and by increasing the potentially beneficial ones (Gomes, Pintado, Freitas \& Silva, 2014). At the present time, some plant products have attracted the attention of researchers to exploit some phytochemicals as antimicrobials and anticancer drugs. Such plant products would be biodegradable and safe for human health (Kumar, Shukla, Singh, Shekhar Prasad \& Kishore Dubey, 2008; Liu, 2004; Wang, Li, Cao \& Jiang, 2010). Therefore, it is necessary to develop new alternative molecules from medicinal plants for their biological activity, such as the treatment of infectious diseases (Boominathan \& Ramamurthy, 2009). At the present time, many new studies have confirmed the antimicrobial activity of polyphenols occurring in medicinal plants. They act as anti-tumour agents, antimicrobials and anti-inflammatory agents (Jayaprakasha, Singh \& Sakariah, 2001; Muanda, Soulimani, Diop \& Dicko, 2011). Zizyphus lotus (L.) was investigated in the present study. Ziziphus lotus (Jujube) is a medicinal plant found in the Mediterranean region, including Algeria (Pottier, 1981). The Zizyphus lotus is a fruit-bearing, thorny shrub belonging to the family Rhamnaceae (Rsaissi \& Bouhache, 2002). In North Africa it is commonly called "Sedra" (Borgi, Ghedira \& Chouchane, 2007). The different species of Zizyphus are widely used in the pharmacobiological field in the treatment of certain diseases such as inflammatory diseases, digestive disorders, weakness, liver diseases, obesity, ur- inary disorders, diabetes, skin infections, fever, diarrhea and insomnia (Abdel-Zaher, Salim, Assaf \& Abdel Hady, 2005; Abu Zarga, Sabri, AlAboudi, Saleh Ajaz \& Sultana, 2004; Suksamrarn et al., 2005).

The present study aims first to investigate the intestinal bacterial community in populations with colorectal cancer and compare it to the bacterial community of healthy adults. Secondly, the objective is to compare the phytochemical screening and evaluation of in vitro antioxidant and antibacterial activities of phenolic extracts from the leaves and stems of Zizyphus lotus (L.). Finally, the effect of this extract as a prebiotic on the aggregation of probiotic and inhibitory effects of pathogenic bacteria isolated from adult patients with colorectal cancer will be investigated.

\section{Materials and Methods}

\section{$2.1 \quad$ Subjects}

A total of 20 adults (12 male and 8 female) were included and divided into 2 groups: group 1 of patients with colorectal cancer $(n=10)$ and group 2 of healthy controls $(n=10)$. Their age ranged between 21 and 34 years, with a mean of $27.6 \pm 2.73$ years for cancerous patients and $26.2 \pm 4.53$ years for healthy controls. Body Mass Index (BMI) had a mean and standard deviation of $22.10 \pm 0.65 \mathrm{~kg} / \mathrm{m}^{2}$ for cancerous patients and $22.05 \pm 1.10 \mathrm{~kg} / \mathrm{m}^{2}$ for healthy controls.

\section{Clinical Characteristics}

Clinical characteristics of groups included in this study are shown in Table 1.

All adults included in this analysis (male or female) were between 19 and 40 years old, having only colorectal cancer disease (Group 1); not having acute or chronic infectious diseases or problems that may affect the gut microbiota (diarrhea, constipation); and not having been treated with antibiotics or antifungals (three months), and chemotherapy. 
Table 1: Clinical characteristics of groups (means $\pm \mathrm{SD}$ )

\begin{tabular}{lll}
\hline $\begin{array}{l}\text { Characteristics } \\
(\mathrm{n}=10)\end{array}$ & $\begin{array}{l}\text { Cancerous patients } \\
(\mathrm{n}=10)\end{array}$ & Healthy controls \\
\hline Male/Female & $6 / 4$ & $6 / 4$ \\
Age (years) & $27.6 \pm 2.73$ & $26.2 \pm 4.53$ \\
Weight $(\mathrm{kg})$ & $61.4 \pm 2.4$ & $64.8 \pm 6.53$ \\
Height $(\mathrm{m})$ & $1.66 \pm 0.027$ & $1.72 \pm 0.04$ \\
Body Mass Index $\left(\mathrm{kg} / \mathrm{m}^{2}\right)$ & $22.10 \pm 0.65$ & $22.05 \pm 1.10$ \\
\hline
\end{tabular}

\section{Ethics}

This work was carried out with the patients' consent and the permission of the director of Yessad Khaled hospital of Mascara.

\subsection{Research and isolation of probiotic and pathogenic Bacteria in patients with colorectal cancer}

\section{Sample preparation}

A $10^{-1}$ dilution was prepared by adding $1 \mathrm{~g}$ of fecal samples to $9 \mathrm{ml}$ of sterile saline. The suspension was mixed for 2 minutes by a vortex. From this suspension serial decimal dilutions were performed up to $10^{-6}$, and $0.1 \mathrm{ml}$ of each dilution was spread on different selective agar media in duplicate.

\section{Clinical isolation and enumeration of bacterial candidates}

Microbiological analysis of the fecal samples was carried out, using various appropriate culture media, to characterize the gut microbiota of different populations. Lactobacillus on MRS (Man Rogosa and Sharpe agar), Streptococcus on M17agar, Total Aerobic and Anaerobic Flora was isolated on GN (Nutrient agar), Enterobacteria was isolated on EMB (Eosin Methylene Blue agar), Staphylococcus on CHAPMAN agar, Enterococcus on BEA (Bile Esculin agar), Clostridium on Liver Meat agar and Bacteroides Blood agar (Béraud, 2001). The plates were incubated at $37{ }^{\circ} \mathrm{C}$ for 24 to 72 hours under aerobic conditions for Lactobacillus, Streptococcus, Total Aerobic Flora, Enterobacteria, Staphylococcus and Enterococcus, and anaerobically for Total Anaerobic Flora, Clostridium and bacteroide. Identification of bacterial candidates found in each culture medium was confirmed by macroscopic examination, Gram staining and use of biochemical tests, API system. Probiotic strains were identified by API $50 \mathrm{CH}$ and characterized for their probiotic potential by evaluation of growth at different temperatures and gastric $\mathrm{pH}$, tolerance of bile salts, resistance to antibiotics, antibacterial activity, aggregation and adhesion capacity. The enumeration of viable bacteria in fecal specimens was performed on dishes with 30-300 colonies and expressed as log colony forming unit (CFU) per gram of fecal sample for statistical reasons and for better mathematical interpretation according to the following formula (Béraud, 2001):

$$
\log \mathrm{CFU} / \mathrm{g}=\frac{\text { Number of colony }}{\text { Dilution } \times \text { Volume seeded }}
$$

\subsection{Phytochemical analysis of Zizyphus lotus}

The plant material consisted of leaves and stems of Zizyphus lotus (L.) from Sidi Benyekhlef in the region of Mascara (Algeria). The plants were collected in July - August 2015. Taxonomic identification was performed by Pr. Najat ELKHIATI (Biological and Health Laboratory, Faculty of Science Aïn Chock-University Hassan II, Casablanca). 


\section{Preparation of plant extracts}

The collected plant samples were air dried for a few days, and then the leaves and stems were crushed into a powder and stored for use.

\section{a Preparation of aqueous extract}

A $5 \mathrm{~g}$ sample of plant material was suspended in $100 \mathrm{ml}$ of distilled water and macerated for $24 \mathrm{~h}$ (Xiao, Han \& Shi, 2008). The macerated material was filtered, and the filtrate was lyophilised and stored at ambient temperature until further use.

\section{b Preparation of methanolic extract}

The powder of plant material (10 g) was extracted with $100 \mathrm{ml}$ of methanol (maceration) during $24 \mathrm{~h}$. After filtration, the filtrate was concentrated under reduced pressure at $40{ }^{\circ} \mathrm{C}$ by rotary evaporator to eliminate the methanol, and the extract was then lyophilized and stored at ambient temperature until further use (Diallo, Sanogo, Yasambou, Traoré \& Maiza, 2004).

\section{Determination of total Phenolic Content}

The amount of total polyphenols was determined according to the Folin-Ciocalteu method. Briefly, $200 \mu \mathrm{l}$ of extract was mixed with $1 \mathrm{ml}$ of $1 / 10$ th Folin-Ciocalteu reagent. After $4 \mathrm{~min}, 0.8 \mathrm{ml}$ of $\mathrm{Na}_{2} \mathrm{CO}_{3}(7.5 \%)$ was added. The mixture was incubated at room temperature for 2 hours and the absorbance was then read using a spectrophotometer at $765 \mathrm{~nm}$ (SHIMADZU-1240 UV/ visible). All determinations were carried out in triplicate. A standard curve was prepared using Gallic acid. Total polyphenolic values are expressed in Gallic Acid Equivalents (GAE) per gram of dry weight (mg GAE/ g DW) (Li et al., 2007).

\section{Estimation of total Flavonoid content}

The determination of total flavonoid content in the various extracts was carried out by a method using aluminium trichloride $\left(\mathrm{AlCl}_{3}\right)$ (Barros, Carvalho \& Ferreira, 2011). Briefly, a $1 \mathrm{ml}$ aliquot of the different extracts was mixed with $0.3 \mathrm{ml}$ of $\mathrm{NaNO}_{2}$ solution (5\%). After $5 \mathrm{~min}$, the resulting mixture was added to $0.3 \mathrm{ml}$ of $\mathrm{AlCl}_{3}$ solution $(10 \%)$, and then after $6 \mathrm{~min}$, this was mixed with $2 \mathrm{ml}$ of $\mathrm{NaOH}(1 \mathrm{M})$ and the total volume made up to $10 \mathrm{ml}$ with distilled water. The absorbance was measured at $510 \mathrm{~nm}$ using a spectrophotometer (SHIMADZU-1240 UV/ visible). A standard curve was prepared using Catechin. Total flavanoid was expressed in milligram Catechin Equivalent (CE) per gram of dry weight (mg EC / g DW).

\section{Estimation of total condensed Tannin content}

The tannin content of plant extracts was determined by the method described by Heimler, Vignolini, Giulia Dini, Vincieri and Romani (2006), using Quercetin as a reference compound. Briefly, $400 \mu \mathrm{l}$ of extract was added to $3 \mathrm{ml}$ of methanolic solution, with $4 \%$ of vanillin, and $1.5 \mathrm{ml}$ of concentrated hydrochloric acid. After $15 \mathrm{~min}$ of incubation, the absorbance was read at $550 \mathrm{~nm}$ using a spectrophotometer (SHIMADZU-1240 UV/ visible). The condensed tannin was expressed in milligram Quercetin Equivalent (QE) per gram of dry weight (mg EQ / g DW) (Heimler et al., 2006).

\section{HPLC Analysis}

Standardization of Phenolic extracts of Zizyphus lotus (L.) by High Performance Liquid Chromatography HPLC-UV was carried out using the optimized conditions. In this analysis, Agilent Technologies 1200 series chromatography equipment was used. For this system, $10 \mu \mathrm{l}$ of each extract was injected onto a C18 reverse phase column. The mobile phase consisted of two eluents, water / methanol mixture (95/5), and the flow rate of the mobile phase was $1 \mathrm{ml} / \mathrm{min}$. The temperature was set at $25^{\circ} \mathrm{C}$. The detector used was a UV detector at a wavelength of 280-320 $\mathrm{nm}$, for $70 \mathrm{~min}$. The results are expressed by a comparison of the chromatograms of the standard with that of the sample. 


\section{Antioxidant activity evaluation: Scavenging ability towards DPPH radical}

This technique depends on the reduction of the free radical DPPH (purple color) to a yellow coloured diphenyl picrylhydrazine in the presence of the antioxidant. Briefly, $25 \mu \mathrm{l}$ of different concentrations of extract were mixed with $2.5 \mathrm{ml}$ solutions of DPPH (0.004\%). Reference antioxidant solutions (ascorbic acid) were also prepared under the same conditions to serve as a positive control. An equal amount of methanol and DPPH served as negative control. After 30 min of incubation at room temperature in the dark, the absorbance was recorded at $517 \mathrm{~nm}$. The experiment was performed in duplicate (Es-Safi, Kollmann, Khlifi \& Ducrot, 2007). The DPPH radical scavenging activity was calculated according to the following equation:

DPPH Scavenging activity $(\%)=\left[\frac{(A 1-A 2)}{A 1}\right] \times 100$

where:

A1: Absorbance of negative control

A2: Absorbance of sample.

\section{Determination of $\mathrm{IC}_{50}$}

The concentration of sample required to scavenge $50 \%$ of $\mathrm{DPPH}\left(\mathrm{IC}_{50}\right)$ was determined graphically from the percent reduction versus concentration curve (Samartha et al., 2008). A decrease in the DPPH solution absorbance indicates an increase in the DPPH radical scavenging activity.

\subsection{Antimicrobial activity evaluation of extract from Zizyphus lotus}

\section{Inoculum preparation}

From a culture of $18 \mathrm{~h}$, a bacterial suspension was prepared to obtain a density equivalent to the standard of 0.5 Mac Farland. This density corresponds to a concentration of $10^{6}-10^{8} \mathrm{CFU}$ / ml (Wade et al., 2001).

\section{Antimicrobial Resistance Testing (Agar Diffusion Method)}

The resistance of the strains to different antimicrobial agents was determined by the disc diffusion method and the antibiotic was chosen according to CASFM (2016). After $24 \mathrm{~h}$ of incubation at $37^{\circ} \mathrm{C}$, the diameter of inhibition zones was measured.

\section{Agar Disc Diffusion Assay}

The in vitro evaluation of antimicrobial activity was carried out using a disc diffusion method. The plant extracts were dissolved in DMSO at $200 \mathrm{mg} / \mathrm{ml}$ with binary dilution. The sterile paper discs (6 mm diameter), impregnated with $10 \mu \mathrm{l}$ of extract of plant per disc, were sterile deposited on the agar surface. The discs were kept at $4{ }^{\circ} \mathrm{C}$ for $1 \mathrm{~h}$ and then incubated for $24 \mathrm{~h}$ at 37 ${ }^{\circ} \mathrm{C}$ (Warda et al., 2009). The disc impregnated with DMSO was used as a negative control. The diameter of the inhibition zone around each disc was measured for three replicates (Kumar et al., 2008).

\section{Determination of MIC by microdilution}

The minimal inhibitory concentration (MIC) of the plant extracts against the different strains was assessed using the microdilution method. Each well of microtiter plates was inoculated with $50 \mu$ l of Broth Muller Hinton (BMH), 50 $\mu \mathrm{l}$ of the extract (dissolved in DMSO) and $50 \mu \mathrm{l}$ of bacterial suspension containing $10^{8} \mathrm{CFU} / \mathrm{ml}$ adjusted to 0.5 McFarland so the final volume in each well was $150 \mu \mathrm{l}$. The positive control was prepared by $50 \mu \mathrm{l} \mathrm{BMH}$ and $50 \mu \mathrm{l}$ of inoculum. The negative control was prepared with $50 \mu \mathrm{l}$ of the extract in solution and $50 \mu \mathrm{l}$ of BMH without inoculum. The microplates were then covered and incubated at $37^{\circ} \mathrm{C}$ for 24 hours (Abdelrahman, Skaug \& Francis, 2002). The turbidity was measured every 2 hours using a microplate reader at $620 \mathrm{~nm}$. Each plant extract was run in duplicate. 
Effect of Zizyphus lotus on some human pathologic bacteria $\mid 165$

\section{Determination of minimal bactericidal concentration (MBC)}

The minimum bactericidal concentration corresponds to the lowest concentration of extracts yielding negative cultures after incubation at 37 ${ }^{\circ} \mathrm{C}$ for $24 \mathrm{~h}$. It was determined by re-plating 10 ul from culture negative wells on Muller Hinton Agar. After $24 \mathrm{~h}$ incubation at $37^{\circ} \mathrm{C}$, the number of colonies on the streaks was compared with those of the bacterial inoculum. All tests were done in triplicate. The MBC / MIC ratio was calculated for each extract. If the result was less than 4, the extract was considered bactericidal (Guinoiseau, 2010).

\subsection{Effect of extracts from Zizyphus lotuson auto-aggregation and co-aggregation}

Autoaggregation and coaggregation abilities of each strain were evaluated. The autoaggregation assay was performed according to the method of Collado, Meriluoto and Salminen (2007) and Tuo et al. (2013) with little modification. The Lactobacillus strains were grown for $18 \mathrm{~h}$ at $37^{\circ} \mathrm{C}$ in MRS broth. Bacterial cells were recovered by centrifugation at $5000 \mathrm{~g} / 15 \mathrm{~min}$, washed twice and resuspended in phosphate buffered saline (PBS, pH 7.2) to obtain an optical density of 0.5 at $600 \mathrm{~nm}$. Cell suspensions $(4 \mathrm{ml})$ were enriched separately by three different volumes of aqueous extract $(50,100$ and $200 \mu \mathrm{l})$. The absorbance at $600 \mathrm{~nm}$ of cell suspensions incubated at $37{ }^{\circ} \mathrm{C}$ was monitored with a spectrophotometer (SHIMADZU-1240 UV/ visible) for different times ( $2 \mathrm{~h}, 4 \mathrm{~h}$ and $24 \mathrm{~h})$.

The results are expressed as a percentage by the following formula:

$$
\text { Autoaggregation }(\%)=\left[1-\left(\frac{A_{t}}{A_{o}}\right)\right] \times 100
$$

where:

$\mathrm{A}_{t}$ represents the absorbance at time $\mathrm{t}=2 \mathrm{~h}, 4$ h, $24 \mathrm{~h}$

$\mathrm{A}_{o}$ the absorbance at time $\mathrm{t}=0 \mathrm{~h}$.

The assay was carried out in triplicate (Collado et al., 2007; Tuo et al., 2013).
Coaggregation assays were also prepared as described for autoaggregation analysis. Briefly, $2 \mathrm{ml}$ of each cell suspension of the different probiotic and pathogen strains were mixed and incubated at $37{ }^{\circ} \mathrm{C}$. Samples were taken in the same way as in the autoaggregation assay. Absorbance was determined for the mixture and for the bacterial suspensions alone. The absorbance $(600 \mathrm{~nm})$ was monitored at different times $(2 \mathrm{~h}, 4 \mathrm{~h}$ and $24 \mathrm{~h})$. Percentages of coaggregation were determined as:

Coaggregation $(\%)=\left\{\frac{\left[\frac{(A x+A y)}{2-A(x+y)}\right]}{A x}+\frac{A y}{2}\right\} \times 100$

where $\mathrm{x}$ and $\mathrm{y}$ each represents one of the two strains in the control tubes, and $(\mathrm{x}+\mathrm{y})$ represents the absorbance of the mixed bacterial suspension.

\subsection{Adhesive interaction assay}

The adhesion ability of each strain was evaluated according to the method of Collado et al. (2007). The hydrophobicity of Lactobacillus strains was determined by Xylene and Toluene extraction. Overnight cultures were harvested by centrifugation, washed twice with PBS (pH 7.2), resuspended in the same buffer, and $A 600$ of the cell suspension was measured to standardize the number of bacteria (approximately $10^{8} \mathrm{CFU} / \mathrm{ml}$ ). An equal volume of Xylene and Toluene was added, and the suspension was vortexed for $4 \mathrm{~min}$. The phases were separated, and the absorbance at 600 $\mathrm{nm}$ of the aqueous phase was measured using a spectrophotometer (SHIMADZU-1240 UV/ visible). The affinity of the bacterial strains to hydrocarbons was reported as adhesion percentage according to the formula:

$$
\text { Hydrophobicity } \%=\left[\frac{\left(A_{0}-A\right)}{A_{0}}\right] \times 100
$$


where $A_{0}$ and $A$ are absorbance values measured before and after Xylene / Toluene extraction.

\section{Statistical analysis}

All experiments were done in triplicate. All data are presented as means $\pm \mathrm{SD}$ or as frequency in percentage $(\%)$. The means were compared using multivariate analysis of variance (ANOVA). $P$ values $<0.05$ were considered significant.

\section{Results and discussion}

\subsection{Microbiological analysis}

The quantitative and qualitative distribution of the different microbial groups included in this study are shown in Figure 1.

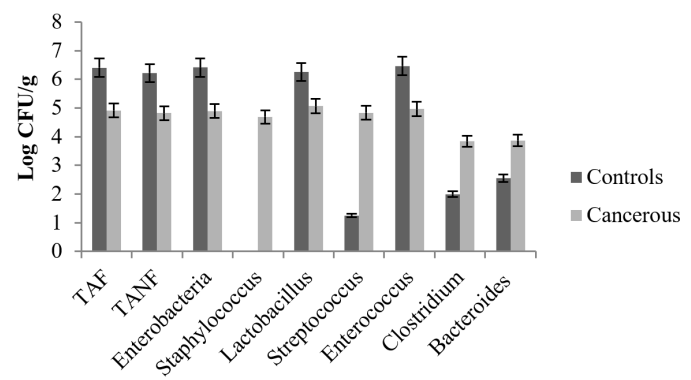

Figure 1: Intestinal microbiota composition in selected groups (cancerous and controls)

The results show that the gut microbiota of patients with colorectal cancer is significantly different than that of the healthy controls. The most difference is the presence of Stapylococcus for the group of cancer patients (4.69 log CFU/g) and its absence in the group of healthy controls. The also was a marked difference for Streptococcus, Clostridium and Bacteroides which were more abundant in patients with colorectal cancer (medians of $4.83 \log \mathrm{CFU} / \mathrm{g}, 3.84 \log \mathrm{CFU} / \mathrm{g}$ and $3.87 \log \mathrm{CFU} / \mathrm{g}$ respectively) than in controls (medians of $1.24 \log \mathrm{CFU} / \mathrm{g}, 1.99 \log \mathrm{CFU} / \mathrm{g}$ and $2.54 \log \mathrm{CFU} / \mathrm{g}$ respectively). However, the microbial groups belonging to the genus Enterobacteria, Lactobacillus and Enterococcus are signific- antly more abundant in healthy controls (medians of $6.41 \log \mathrm{CFU} / \mathrm{g}, 6.25 \log \mathrm{CFU} / \mathrm{g}$ and 6.46 $\log \mathrm{CFU} / \mathrm{g}$ respectively) than in patients with colorectal cancer (medians of $4.89 \log \mathrm{CFU} / \mathrm{g}$, $5.06 \log \mathrm{CFU} / \mathrm{g}$ and $4.96 \log \mathrm{CFU} / \mathrm{g}$ respectively).

\subsection{Firmicutes/Bacteroidetes ratio}

In this study for the Firmicutes/Bacteroidetes ratio, there was a significant difference between healthy controls and patients with colorectal cancer (0.6 and 0.7 respectively). The ratio is significantly higher in cancer patients that in healthy controls. Similar findings were reported in the study of Chen et al. (2012) which showed more abundant Firmicutes and less abundant Bacteroidetes in groups of patients with CRC. Gao, Guo, Gao, Zhu and Qin (2015) showed that cancerous tissue had a significantly higher abundance of Firmicutes and Fusobacteria than tissue found in healthy individuals. Another study reported that a reduction in Bacteroidetes diversity and an increase in Firmicutes and Fusobacteria diversity were observed in CRC samples, suggesting that specific bacteria could play a major role in CRC (Allali, 2017).

\subsection{Microbial strains selection for aggregation and adhesion capacity}

After identification, the following pathogenic microorganisms Citrobacter braakii, Enterobacter cloacae, Escherichia coli, Staphylococcus aureus, Enterococcus faecalis and Clostridium leptum, and the probiotic strains, Lactobacillus salivarius were selected for aggregation and adhesion tests.

\subsection{Phytochemical analysis of Zizyphus lotus 1}

\section{Extraction Yield}

The results obtained show that the yield of extracts from Ziziphus lotus varies according to the solvent used. The greatest yield was observed 
with the aqueous extract (32.92\%), followed by the methanolic extract $(30.84 \%)$. The yield of extracts depends on several factors, such as the origin of the plant (Ebrahimzadeh, Pourmorad \& Hafezi, 2008), the variety, the harvest season, the climatic and environmental conditions, the geographical location, the different diseases that can affect the plant, the maturity of the plant (Park $\&$ Cha, 2003) and the method of extraction.

\section{Phytochemical analysis}

Aqueous and methanol extracts were prepared to examine the content of total phenolics, flavonoids and tannins. The results for extractive values are tabulated in Table 2.

The total phenolics content varied among the extracts as shown in Table 2. Zizyphus lotus extracts showed the higher polyphenol content (225.40 mg AGE / g DW) in the aqueous extract than in the methanolic extract (63.04 mg GAE/gDW). This could be due to different degrees of polarity of the solvents used for the extraction of the polyphenolic compounds. $\mathrm{AE}$ and $\mathrm{ME}$ extracts of leaves of Zizyphus lotus appear richer in polyphenols. In a study by Hossain, Uddin and Islam (2015), the extract of Zizyphus lotus contained a total phenolic content of $97.18 \pm 12.81 \mathrm{mg}$ of gallic acid equivalents /g DW. Zizyphus lotus extracts showed the higher flavonoids content (14.88 mg CE/gDW) in the methanolic extract than in the aqueous extract $(11.30 \mathrm{mg} \mathrm{CE} / \mathrm{gDW})$. The concentration of flavonoids in plant extracts depends on the polarity of solvents used in the extract preparation (Gao \& Liu, 2005). The presence of flavonoids in leaves of Zizyphus lotus extracts have been reported to be responsible for antioxidant activity (Braca et al., 2003).

For condensed tannin contents, higher values were observed in the aqueous extract (10.66 $\mathrm{mg} \mathrm{QE} / \mathrm{gDW}$ ) than in the methanolic extract (8.66 $\mathrm{mg} \mathrm{QE} / \mathrm{gDW}$ ). The presence of tannins in some plant extracts indicates that the plant may have the ability to be an antioxidant, antifungal and anti-inflammatory agent, and possess healing properties (Araujo, Alencar, Lucia Cavalcanti de Amorim \& Albuquerque, 2008).

\section{HPLC analysis}

Preliminary analysis for the extracts of the aerial parts of this plant showed chromatographic profiles almost similar from a qualitative point of view but with a quantitative difference in the abundance of their majority compounds. The chromatographic profiles of the extracts EA and EM are shown in Table 3 and 4 respectively.

The chromatographic profile for quantitative and qualitative analysis (HPLC) of extracts is shown in Tables 3 and 4. During these analyses, 13 components were identified. The phytochemical analysis by HPLC showed that all extracts are rich in phenolic compounds. The aqueous extract is mainly composed of Quercetin glucosid (36.35\%), Resveratrol (34.31\%), Kaempferol glucosid (8.18\%), Miricitine (3.19\%), Kaempferol $(2.9 \%)$, Gallic acid (1.06\%) and Quercetin $(1.03 \%)$. Other components such as Caffeic acid $(0.70 \%)$, Epigalocatechin $(0.34 \%)$, Epigalocatechin gallate $(0.28 \%)$, Catechin $(0.25 \%)$ and Procyanidin B2 $(0.23 \%)$ are also present but with lower concentrations.

A comparison with the methanolic extract showed it to be composed of Quercetin glucosid (33.27\%), Resveratrol (16.89\%), Kaempferol glucosid (6.26\%), Quercetin (3.33\%), Kaempferol $(3.13 \%)$, Miricitine $(3.09 \%)$, Caffeic acid $(2.87 \%)$, Catechin $(2.83 \%)$, Procyanidin B2 $(2.24 \%)$, Epigalocatechin gallate $(1.1 \%)$ and Gallic acid $(0.45 \%)$.

Other components such as Epigalocatechin $(0.10 \%)$ and Catechin hydrate $(0.08 \%)$ are also present but with lower concentrations. Some trace compounds can significantly increase the biological activity of medicinal plants (Vamanu \& Nita, 2013). Plants with high levels of phenolic compounds have been shown to exhibit high antioxidant capacity (Razali, Razab, Junit \& Abdul Aziz, 2008).

\section{Antioxidant activity}

The antioxidant activity of our extracts is expressed in $\mathrm{IC}_{50}$ (Table 5). This parameter has been used by several research groups to present their results. It defines the effective concentration of the substrate that causes the loss of $50 \%$ of the activity of $\mathrm{DPPH}$. Lower $\mathrm{IC}_{50}$ values in- 
Table 2: Total phenolic, flavonoid and tannin contents in the plant extracts

\begin{tabular}{|c|c|c|c|c|c|}
\hline Sample & \multicolumn{2}{|c|}{$\begin{array}{l}\text { Polyphenol content } \\
(\mathrm{mgAGE} / \mathrm{gDW})^{a *} \pm \mathrm{SD}\end{array}$} & \multicolumn{2}{|c|}{$\begin{array}{l}\text { Flavonoid content } \\
(\mathrm{mgCE} / \mathrm{gDW})^{b *} \pm \mathrm{SD}\end{array}$} & $\begin{array}{l}\text { Tannin } \\
(\mathrm{mgQF}\end{array}$ \\
\hline \multirow{2}{*}{$\begin{array}{l}\text { Aqueous extract (AE) } \\
\text { Methanolic extract (ME) }\end{array}$} & \multicolumn{2}{|l|}{$225.40 \pm 0.28$} & \multicolumn{2}{|c|}{$11.30 \pm 0.20$} & 10.66 \\
\hline & \multicolumn{2}{|l|}{$63.04 \pm 0.58$} & \multicolumn{2}{|c|}{$14.88 \pm 0.37$} & $8.66 \pm$ \\
\hline \multicolumn{6}{|c|}{$\begin{array}{l}{ }^{*} \text { Mean } \pm \text { SD of three determinations } \\
{ }^{a} \text { mg acid galic equivalent/g dry weight. }{ }^{b} \text { mg catechin equivalent/g dry weight. } \\
{ }^{c} \text { mg Quercetin equivalent / g dry weight }\end{array}$} \\
\hline \multicolumn{6}{|c|}{ Table 3: Chromatographic profile of aqueous extracts } \\
\hline & Components & \multicolumn{2}{|c|}{ Retention time (min) } & \multicolumn{2}{|c|}{ Percentage $(\%)$} \\
\hline & Gallic Acid & \multicolumn{2}{|l|}{7.30} & \multicolumn{2}{|l|}{1.0609} \\
\hline & Catechin & 17.59 & \multicolumn{3}{|c|}{0.3466} \\
\hline & Epigalocatechin & 17.92 & \multicolumn{3}{|c|}{0.3466} \\
\hline & Procyanidin B2 & 19.94 & \multicolumn{3}{|c|}{0.2393} \\
\hline & Caffeic acid & 21 & \multicolumn{3}{|c|}{0.7062} \\
\hline & Epigalocatechin gallate & 22.54 & \multicolumn{3}{|c|}{0.2861} \\
\hline & Resveratrol & 36 & \multicolumn{3}{|c|}{34.3188} \\
\hline & Quercetin glucoside & 36.7 & \multicolumn{3}{|c|}{36.3544} \\
\hline & Miricitine & 38.5 & \multicolumn{3}{|c|}{3.1961} \\
\hline & Kaempferol glucoside & 39.7 & \multicolumn{3}{|c|}{8.1833} \\
\hline & Quercetin & 42 & \multicolumn{3}{|c|}{1.0331} \\
\hline & Kaempferol & 46 & & 2.5935 & \\
\hline
\end{tabular}

Table 4: Chromatographic profile of methanolic extracts

\begin{tabular}{lll}
\hline Components & Retention time $(\mathrm{min})$ & Percentage $(\%)$ \\
\hline Gallic Acid & 7.30 & 0.4573 \\
Catechin hydrate & 17 & 0.0807 \\
Catechin & 17.59 & 2.8301 \\
Epigalocatechin & 17.92 & 0.1047 \\
Procyanidin B2 & 19.94 & 2.2410 \\
Caffeic acid & 21 & 2.8711 \\
Epicatechin gallate & 27.88 & 1.3186 \\
Resveratrol & 36 & 16.8941 \\
Quercetin glucoside & 36.7 & 33.2753 \\
Miricitine & 38.5 & 3.0955 \\
Kaempferol glucoside & 39.7 & 6.2677 \\
Quercetin & 42 & 3.3308 \\
Kaempferol & 46 & 3.1372 \\
\hline
\end{tabular}


dicate higher antioxidant activity (Pokorny \& Schmidt, 2001).

The $\mathrm{IC}_{50}$ value was determined from a graph of scavenging activity against the different concentrations of Zizyphus lotus extracts and ascorbic acid. The $50 \%$ inhibition concentrations $\left(\mathrm{IC}_{50}\right)$ are shown in Table 5. They are relatively low, reflecting the presence of compounds that can reduce the $\mathrm{DPPH}$ radical.

According to the results shown in Figure 2, our mostly methanolic extracts have more interesting DPPH free radical neutralization capabilities $(195 \pm 0.02 \mu \mathrm{g} / \mathrm{ml})$ than aqueous extracts $(227 \pm 0.01 \mu \mathrm{g} / \mathrm{ml})$. This finding is supported by the study of Sun, Powers and Tang (2007) which showed that methanol remains the best solvent to extract antioxidants from a plant, although still significantly lower than ascorbic acid (36 \pm 0.03 $\mu \mathrm{g} / \mathrm{ml})$. Much of the antioxidant potential of medicinal plants is due to the redox properties of phenolic compounds. They act as reducing agents, hydrogen donors and singlet oxygen scavengers (Hakkim, Gowri Shankar \& Girija, 2007).

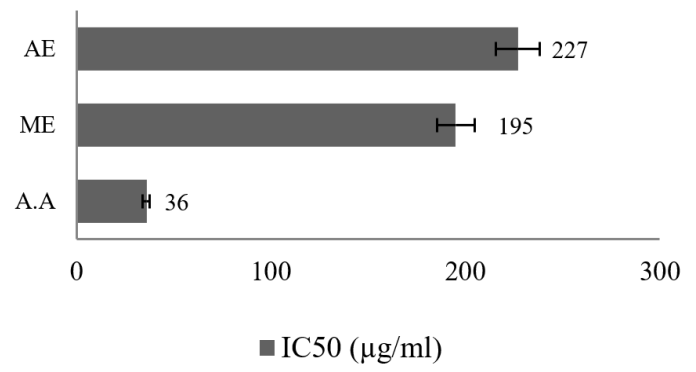

Figure 2: Inhibition concentrations $\left(\mathrm{IC}_{50}\right)$ of the plant extracts

\subsection{Antimicrobial activity}

\section{Antimicrobial activity of selected antibiotics}

The antibiotic resistance of strains was determined from the diameter of the zone of inhibition (mm) according to the Committee of the Antibiogram of the French Society of Microbiology
(CASFM, 2016). The results of the antimicrobial activity of selected antibiotics are reported in Table 6.

\section{Disc diffusion test}

The results of the antimicrobial activity of extracts against the strains of bacteria tested by the method of aromatogram are shown in Table 7 .

From the disc diffusion test results, it appears that all bacterial strains tested are inhibited by phenolic extracts, with various degrees of antimicrobial activity. This confirms the broad spectrum of antimicrobial activity of these extracts against Gram+ and Gram- bacteria. Large zones of inhibition appear with the methanolic extract against Escherichia coli and Citrobacter braakii (35-29 mm), respectively. The aqueous extracts are also more active against Escherichia coli $(32 \mathrm{~mm})$. This plant extract exhibited a significant antibacterial activity against the different strains of antibiotics. However, these activities of extract are due to its content of active compounds.

The antimicrobial activity of these extracts against bacterial strains could be attributed to the presence of biologically active components such as flavonoids, phenolic acids and terpenoids as described in the chromatogram (Doudach et al., 2012).

\section{Minimum inhibitory concentration (MIC)}

Results of the antimicrobial activity of extracts against the strains of bacteria tested by microdilution are shown in Table 8.

According to Table 8, the plant extract had an important inhibitory activity against bacteria tested. The highest activity against strains tested with MIC was $6.25-25 \mathrm{mg} / \mathrm{ml}$ for aqueous extract and $12.5-25 \mathrm{mg} / \mathrm{ml}$ for methanolic extract. However, AE was more active against E.coli, Enterobacter cloacae and Citrobacter braakii $(6.25 \mathrm{mg} / \mathrm{ml})$ and $\mathrm{ME}$ were more active against Enterococcus faecalis and Clostridium leptum $(12.5 \mathrm{mg} / \mathrm{ml})$.

The antibacterial activity can be explained by 
$170 \mid$ Ouldchikh et al.

Table 5: The antioxidant activity of the plant extracts

\begin{tabular}{ll}
\hline Sample & $\mathrm{DPPH}\left(\mathrm{IC}_{50}, \mu \mathrm{g} / \mathrm{ml}\right)$ \\
\hline Aqueous extract $(\mathrm{AE})$ & $227 \pm 0.01$ \\
Methanolic extract $(\mathrm{ME})$ & $195 \pm 0.02$ \\
Ascorbic acid (AA) & $36 \pm 0.03$ \\
\hline
\end{tabular}

Table 6: Antibiotic resistance profile of tested bacterial strains

\begin{tabular}{llllllllll}
\hline & AMC & CN & OX & V & C & TE & SXT & L & ATM \\
\hline Escherichia coli & $\mathrm{R}$ & $\mathrm{I}$ & $/$ & $/$ & $\mathrm{S}$ & $\mathrm{R}$ & $\mathrm{R}$ & $/$ & $\mathrm{R}$ \\
Enterobacter cloacae & $\mathrm{R}$ & $\mathrm{I}$ & $/$ & $/$ & $\mathrm{I}$ & $\mathrm{R}$ & $\mathrm{R}$ & $/$ & $\mathrm{R}$ \\
Citrobacter braakii & $\mathrm{R}$ & $\mathrm{I}$ & $/$ & $/$ & $\mathrm{S}$ & $\mathrm{R}$ & $\mathrm{R}$ & $/$ & $\mathrm{I}$ \\
Staphylococcus aureus & $/$ & $\mathrm{I}$ & $\mathrm{R}$ & $\mathrm{R}$ & $\mathrm{S}$ & $\mathrm{I}$ & $\mathrm{R}$ & $\mathrm{R}$ & $/$ \\
Enterococcus faecalis & $/$ & $\mathrm{I}$ & $/$ & $\mathrm{R}$ & $\mathrm{S}$ & $\mathrm{S}$ & $\mathrm{I}$ & $\mathrm{R}$ & $/$ \\
Clostridium leptum & $\mathrm{R}$ & $\mathrm{I}$ & $/$ & $\mathrm{R}$ & $\mathrm{I}$ & $/$ & $/$ & $\mathrm{R}$ & $\mathrm{R}$ \\
\hline
\end{tabular}

R: Resistant, I: Intermediate, S: Susceptible, AMC: Amoxicillin+ Clavulanic acid, CN: Gentamycin, OX:Oxacillin, V: Vancomycin, C: Chloramphenicol, TE:

Tetracyclin, SXT: Trimethoprin/Sulfamethoxazol, L: Lincomycin, ATM: Aztreonam

Table 7: The diameter of the zone of inhibition $(\mathrm{mm})$ from plant extracts for pathogenic bacteria

\begin{tabular}{|c|c|c|c|c|}
\hline & \multicolumn{4}{|c|}{ Inhibition diameter $(\varnothing \mathrm{mm})$} \\
\hline & Aqueous extract (AE) & Methanolic extract (ME) & OX $5 \mu \mathrm{g}$ & $\mathrm{CN} 10 \mu \mathrm{g}$ \\
\hline Escherichia coli & $32 \pm 0.8$ & $35 \pm 0.12$ & & $14 \pm 0.1$ \\
\hline Enterobacter cloacae & $20 \pm 0.06$ & $21 \pm 0.3$ & & $11 \pm 0.8$ \\
\hline Citrobacter braakii & $18 \pm 0.2$ & $29 \pm 0.01$ & & $13 \pm 0.2$ \\
\hline Staphylococcus aureus & $16 \pm 0.17$ & $22 \pm 0.15$ & _- & \\
\hline Enterococcus faecalis & $23 \pm 0.35$ & $20 \pm 0.08$ & _- & $11 \pm 0.09$ \\
\hline Clostridium leptum & $16 \pm 0.57$ & $20 \pm 0.03$ & & $10 \pm 0$ \\
\hline
\end{tabular}


the mechanism of toxicity towards the halforganisms, which is done either by non-specific interactions such as the establishment of hydrogen bridges with the proteins of the cell walls or the enzymes, either by the chelation of metal ions (such as iron) and the imprisonment of the substances necessary for the growth of bacteria (Karou et al., 2005).

\section{Minimum bactericidal concentrations (MBC)}

Minimum bactericidal concentrations of extracts are reported in Table 9.

The highest activity against strains tested with MBC was 25-50 $\mathrm{mg} / \mathrm{ml}$ for aqueous extracts and $25-100 \mathrm{mg} / \mathrm{ml}$ for methanolic extracts (Table 9). For the MBC / MIC ratio, the extract is validated as bactericidal when it is less than or equal to 4. Values of this ratio are variable for the various extracts according to the bacterial strains tested (Table 9), which makes it possible to establish a classification of these extracts according to their spectrum of action. Indeed, some work has shown that Flavonoids such as Quercetin and Apigenin are involved in the inhibition of D-alanine: D-alanine ligase, thus disrupting the synthesis of the bacterial wall $(\mathrm{Wu}$ et al., 2008). Other authors have speculated that certain Flavonoids belonging to the class of Flavonols (Cushnie \& Lamb, 2005), the flavan3-ols (Sirk, Brown, Sum \& Friedman, 2008) cause an alteration of the cytoplasmic membrane leading to its lysis, or the inhibition of topoisomerase by Isoflavonoids, thus blocking the synthesis of deoxyribonucleic acid (DNA) (Gradisar, Pristovsek, Andreja \& Jerala, 2007; Wang et al., 2010).

\section{Effect of extract on autoaggregation and coaggregation}

The in vitro effect of aqueous extract of Zizyphus lotus in auto and coaggregation of bacteria strains was evaluated. The viability of Lactobacillus salivarius was carried out on agar. The incorporation of $200 \mu \mathrm{l}$ of aqueous extract had no effect on the development of probiotic strains tested.
As shown in Figure 3, autoaggregation of Lactobacillus salivarius, without aqueous extract, increased in time from $45.9 \%$ to $55.6 \%$ for $2 \mathrm{~h}$ and 4 $\mathrm{h}$ respectively to $79.6 \%$ and $91.2 \%$ for $2 \mathrm{~h}$ and $4 \mathrm{~h}$ respectively, in the presence of aqueous extract. After $24 \mathrm{~h}$, the highest autoaggregation capacities were recorded of $81.20 \%$ and $93.4 \%$ respectively, without and with aqueous extract. The difference is statistically significant $(\mathrm{P}<0.05)$ compared to control (without AE).

The high autoaggregation capacity suggests that the probiotic strain is good at forming biofilms and/or gastrointestinal tract colonization, which are the ways of forming barriers against colonization by pathogenic microorganisms (Schachtsiek, P. Hammes \& Hertel, 2005).

Coaggregation of Lactobacillus salivarius with potential gut pathogens could contribute to the positive properties of the probiotic. As shown in Figure 4, the strain Lactobacillus salivarius showed the highest coaggregating ability with Clostridium leptum, which without aqueous extract was $72.61 \%$ and in the presence of aqueous extract was $73.20 \%$. Coaggregation is a process by which bacteria are attached to each other by means of specific molecules (Rickard, Gilbert, J. High, E. Kolenbrander \& S. Handley, 2003). The percentage of coaggregation, without aqueous extract, of Escherichia coli, Enterobacter cloacae, Citrobacter brakii, Staphylococcus aureus and Enterococcus fecalis respectively was $8.66 \%, 57.75 \%, 72.40 \%, 56.65 \%$ and $48.98 \%$. However, the respective percentage of coaggregation increased to $69.75 \%, 64.80 \%$, $77.32 \%, 70.40 \%$ and $52.64 \%$ in the presence of aqueous extracts from Zizyphus lotus $(L)$. The difference is statistically significant $(\mathrm{P}<0.05)$ compared to control (without AE).

The coaggregation of probiotic-pathogen improved in the presence of the extract. A study by Alberto, Rinsdahl Canavosio and Manca de Nadra (2006) showed that flavonoids can prevent the expression of adhesion molecules, in particular human endothelial cells, and the inhibitory effect of the tumor factor NF- $\alpha \beta$ inducing the expression of adhesion molecules. This effect depends on the molecular structure, concentration and metabolic transformation of flavonoids. In another study, El Astal, Ashour and Kerrit (2005) suggested that plants have a variety 
$172 \mid$ Ouldchikh et al.

Table 8: The minimum inhibitory concentrations (MIC) of plant extracts and antibiotic

\begin{tabular}{|c|c|c|c|c|}
\hline & \multicolumn{2}{|c|}{ Extracts of Zizyphus lotus (L.) $(\mathrm{mg} / \mathrm{ml})$} & \multicolumn{2}{|c|}{ Antibiotics $(\mu \mathrm{g} / \mathrm{ml})$} \\
\hline & Aqueous extract (AE) & Methanolic extract (ME) & OX & $\mathrm{CN}$ \\
\hline Escherichia coli & 6.25 & 25 & & 62.5 \\
\hline Enterobacter cloacae & 6.25 & 25 & & 125 \\
\hline Citrobacter braakii & 6.25 & 25 & & 250 \\
\hline Staphylococcus aureus & 25 & 25 & 62.5 & \\
\hline Enterococcus faecalis & 12.5 & 12.5 & & 125 \\
\hline Clostridium leptum & 12.5 & 12.5 & & 125 \\
\hline
\end{tabular}

Table 9: The minimum bactericidal concentrations (MBC) and MBC/MIC ratio of plant extracts

\begin{tabular}{lllll}
\hline & MBC $(\mathrm{mg} / \mathrm{ml})$ & & MBC/MIC ratio \\
& $\mathrm{AE}$ & $\mathrm{ME}$ & $\mathrm{AE}$ & $\mathrm{ME}$ \\
\hline Escherichia coli & 25 & 25 & 4 & 1 \\
Enterobacter cloacae & 50 & 25 & 8 & 1 \\
Citrobacter braakii & 25 & 25 & 4 & 1 \\
Staphylococcus aureus & 25 & 100 & 1 & 4 \\
Enterococcus faecalis & 25 & 25 & 2 & 2 \\
Clostridium leptum & 25 & 25 & 2 & 2 \\
\hline
\end{tabular}

of potentially significant therapeutic compounds against human pathogenic bacteria.

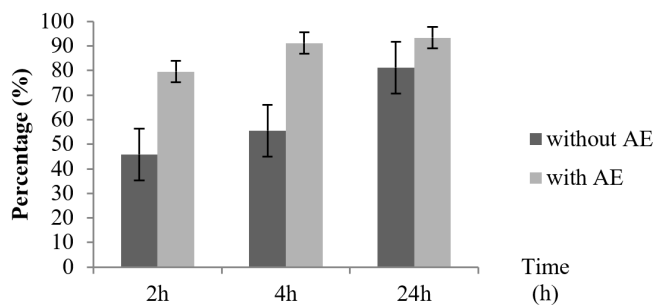

Figure 3: Effect of aqueous extract on autoaggregation of Lactobacillus salivarius

\section{Capacity of Bacteria adhesion}

As shown in Figure 5, Lactobacillus salivarius presents an important adhesion capacity of $67.52 \%$ and $65.31 \%$ for xylene and Toluene respectively. The hydrophobic nature of the outermost surface of microorganisms has been in-

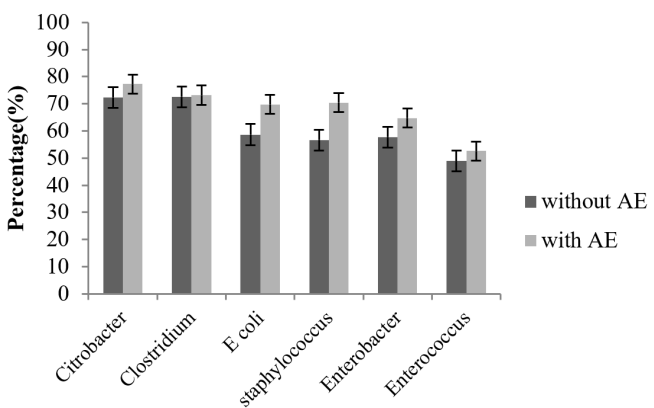

Figure 4: Effect of aqueous extract on coaggregation of bacteria strains tested

volved in the attachment of bacteria to host tissue. This property could confer an important advantage for bacterial maintenance in the human gastrointestinal tract (Schillinger, Guigas \& Holzapfel, 2005). One of the main criteria in the selection of probiotic bacteria is the ability to adhere to the intestinal mucus because the adhesion extends their permanence in the intestine, which 
allows them to exert a salutary effect (Apostolou et al., 2001) and to improve the antagonistic activity against enteropathogens (Leahy, Higgins, Fitzgerald \& Van Sinderen, 2005).

The adhesion of probiotics to the intestinal mucosa and enterocytes is considered an important factor in the colonization of the intestinal tract and the modulation of the immune system of the host (Ouwehand, Isolauri \& Salminen, 2002).

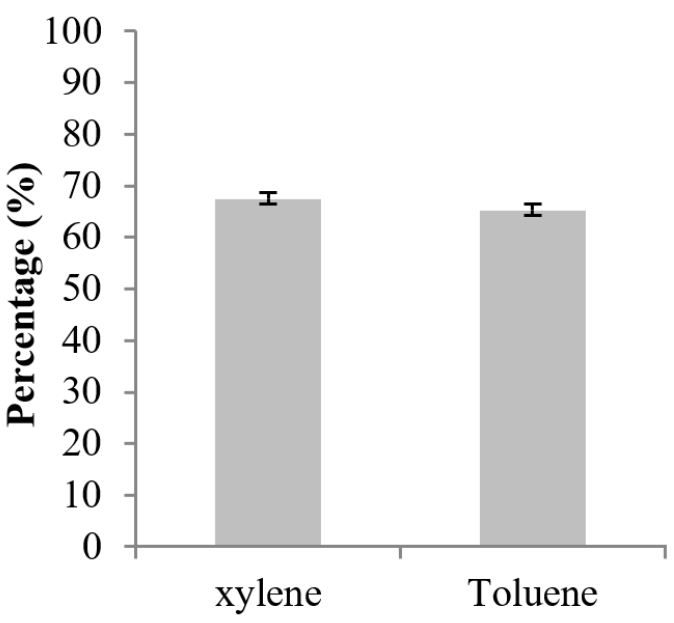

Figure 5: Percentage of adhesion of Lactobacillus salivarius to solvents

\section{Conclusions}

The presence of certain bacterial species has an impact on the development of CRC. Therefore, it is imperative to study the intestinal microbiota during $\mathrm{CRC}$ and the bacterial resistance to drugs, and to research a natural strategy that relieves the restoration and modulation of the gut microbiota.

This work confirms the prebiotic, antioxidant and antibacterial activity of extracts from Zizyphus lotus. It also confirms the stimulatory effect of the aqueous extract on probiotic aggregation and the inhibitory effect of Lactobacillus salivarius against the pathogenic bacteria tested (Citrobacter braakii, Enterobacter cloacae, Escherichia coli, Staphylococcus aureus, Enterococcus faecalis, Clostridium leptum) which were isol- ated from feces of patients with colorectal cancer. Autoaggregative and Coaggregative capacities can be used for preliminary selection of probiotic bacteria for potential applications in humans to modulate and keep the microflora balance by development of probiotics and the reduction of pathogenic bacteria responsible for many diseases.

\section{Acknowledgements}

The authors are grateful to MESRS and to DGRSDT from Algeria for their financial support to this project.

\section{References}

Abdel-Zaher, A. O., Salim, S. Y., Assaf, M. \& Abdel Hady, R. (2005). Antidiabetic activity and toxicity of zizyphus spina-christi leaves. Journal of Ethnopharmacology, 101, 129-38. doi:10.1016/j.jep.2005.04.007

Abdelrahman, H., Skaug, N. \& Francis, G. (2002). In vitro antimicrobial effects of crude miswak extracts on oral pathogens. Saudi Dent J, 14, 26-32.

Abu Zarga, M., Sabri, S., Al-Aboudi, A., Saleh Ajaz, M. \& Sultana, N. (2004). New cyclopeptide alkaloids from Zizyphus lotus. Journal of Natural Products, 58. doi:10. 1021/np50118a004

Alberto, M. R., Rinsdahl Canavosio, M. A. \& Manca de Nadra, M. C. (2006). Antimicrobial effect of polyphenols from apple skins on human bacterial pathogens. Electronic Journal of Biotechnology. doi:10.2225 / vol9-issue3-fulltext-1

Allali, I. (2017). Etude d'association entre le microbiome intestinal et le cancer colorectal chez la population marocaine.

Apostolou, E., Kirjavainen, P., Saxelin, M., Rautelin, H., Valtonen, V., Salminen, S. \& Ouwehand, A. (2001). Good adhesion properties of probiotics: A potential risk for bacteremia? FEMS Immunology and Medical Microbiology, 31, 35-9. doi:10.1111/j. 1574-695X.2001.tb01583.x 
Araujo, T., Alencar, N., Lucia Cavalcanti de Amorim, E. \& Albuquerque, U. (2008). A new approach to study medicinal plants with tannins and flavonoids contents from the local knowledge. journal of ethnopharmacology. Journal of Ethnopharmacology, 120, 72-80. doi:10.1016/j.jep.2008.07.032

Azcarate-Peril, M., Sikes, M. \& Bruno-Barcena, J. (2011). The intestinal microbiota, gastrointestinal environment and colorectal cancer: A putative role for probiotics in prevention of colorectal cancer? American Journal of Physiology. Gastrointestinal and Liver Physiology, 301, G401-424. doi:10. 1152/ajpgi.00110.2011

Backhed, F., Ley, R., L Sonnenburg, J., Peterson, D. \& I Gordon, J. (2005). Host-bacterial mutualism in the human intestine. Science (New York, N.Y.) 307, 1915-20. doi:10. 1126/science.1104816

Barros, L., Carvalho, A. \& Ferreira, I. (2011). Exotic fruits as a source of important phytochemicals: Improving the traditional use of rosa canina fruits in Portugal. Food Research International, 44, 22332236. doi:10.1016/j.foodres.2010.10.005

Béraud, N. (2001). The biological analysis technician, theoretical and practical guide. Tec Doc, Lavoisier, 988-990.

Boominathan, M. \& Ramamurthy, V. (2009). Antimicrobial activity of Heliotropium indicum and Coldenia procumbens. Journal of Ecobiology, 24 (1), 11-15.

Borgi, W., Ghedira, K. \& Chouchane, N. (2007). Antiinflammatory and analgesic activities of Zizyphus lotus root barks. Fitoterapia, 78, 16-9. doi:10.1016/j.fitote.2006.09.010

Braca, A., Politi, M., Sanogo, R., Sanou, H., Morelli, I., Pizza, C. \& Tommasi, N. (2003). Chemical composition and antioxidant activity of phenolic compounds from wild and cultivated Sclerocarya birrea (anacardiaceae) leaves. Journal of Agricultural and Food Chemistry, 51, 6689-95. doi:10.1021/jf030374m

CASFM. (2016). Committee of the antibiogram of the french society of microbiology. Retrieved from https : / / www . sfm microbiologie.org/
Chen, Weiguang, Liu, Fanlong, Ling, Zongxin, .. Charlie. (2012). Human intestinal lumen and mucosa-associated microbiota in patients with colorectal cancer. PLOS ONE, 7(6), 1-9. doi:10.1371/journal.pone. 0039743

Collado, M. C., Meriluoto, J. \& Salminen, S. (2007). Adhesion and aggregation properties of probiotic and pathogen strains. European Food Research and Technology, 226, 1065-1073. doi:10.1007/s00217-007$0632-\mathrm{x}$

Cushnie, T. \& Lamb, A. (2005). Detection of galangin-induced cytoplasmic membrane damage in Staphylococcus aureus by measuring potassium loss. Journal of Ethnopharmacology, 101, 243-8. doi:10.1016/j . jep.2005.04.014

Diallo, D., Sanogo, R., Yasambou, H., Traoré, K., A. andCoulibaly \& Maiza, A. (2004). Étude des constituants des feuilles de Ziziphus mauritiana Lam. (rhamnaceae) utilisées traditionnellement dans le traitement du diabète au mali. Comptes Rendus Chimie - C R CHIM, 7, 1073-1080. doi:10.1016/j. crci.2003.12.035

Doudach, L., Meddah, B., Alnamer, R., Faouzi, M., Chibani, F., Abdelhakim, E. \& Cherrah, Y. (2012). In vitro antibacterial potential activity of the methanolic and aqueous extracts of corrigiola telephiifolia pourr. and mesembryanthemum nodiflorum. Journal of Biologically Active Products from Nature, 2(5), 284-291. Retrieved from 10.1080/22311866.2012. 10719136

Ebrahimzadeh, M., Pourmorad, F. \& Hafezi, S. (2008). Antioxidant activities of iranian corn silk. Turkish Journal of Biology, 32, 43-49.

El Astal, Z. Y., Ashour, A. E. R. A. \& Kerrit, A. A. M. (2005). Antimicrobial activity of some medicinal plant extracts in palestine. Pak. J. Med. Sci, 21(2), 187-193. Retrieved from www.pjms.com.pk

Gao, M. \& Liu, C.-Z. (2005). Comparison of techniques for the extraction of flavonoids from cultured cells of Saussurea medusa Maxim. World Journal of Microbiology and Bio- 
Effect of Zizyphus lotus on some human pathologic bacteria $\mid 175$

technology, 21, 1461-1463. doi:10.1007/ s11274-005-6809-1

Gao, Z., Guo, B., Gao, R., Zhu, Q. \& Qin, H. (2015). Microbiota disbiosis is associated with colorectal cancer. Frontiers in Microbiology, 6, 20. doi:10 . 3389/ fmicb. 2015 . 00020

Gomes, A., Pintado, M., Freitas, A. \& Silva, J. P. (2014). Gastrointestinal tract: Microflora and transit aspects. (pp. 7-45). doi:10. 4032/9789814411639

Gradisar, H., Pristovsek, P., Andreja, P. \& Jerala, R. (2007). Green Tea Catechins Inhibit Bacterial DNA Gyrase by Interaction with Its ATP Binding Site. Journal of Medicinal Chemistry, 50, 264-271. doi:10.1021/ jm060817o

Guinoiseau, E. (2010). Molécules antibactériennes issues d'huiles essentielles: Séparation, identification et mode d'action (Doctoral dissertation).

Hakkim, L., Gowri Shankar, C. \& Girija, S. (2007). Chemical composition and antioxidant property of holy basil (Ocimum sanctum l.) leaves, stems, and inflorescence and their in vitro callus cultures. Journal of $\mathrm{Ag}$ ricultural and Food Chemistry, 55, 910917. doi:10.1021/jf071509h

Heimler, D., Vignolini, P., Giulia Dini, M., Vincieri, F. \& Romani, A. (2006). Antiradical activity and polyphenol composition of local brassicaceae edible varieties. Food Chemistry, 99, 464-469. doi:10.1016/j . foodchem.2005.07.057

Hossain, M. S., Uddin, N. \& Islam, A. (2015). Evaluation of in vitro antioxidant and brine shrimp lethality activities of different stem extracts of Zizyphus rugosa Lam. Food Measure, 9, 454-462. doi:10.1007/s11694015-9253-4

Jayaprakasha, G., Singh, R. \& Sakariah, K. (2001). Antioxidant activity of grape seed (vitis vinifera) extracts on peroxidation models in vitro. Food Chemistry, 73, 285290. doi:10.1016/S0308-8146(00)00298-3

Jemal, A., Bray, F., Center, M. M., Ferlay, J., Ward, E. \& Forman, D. (2011). Global cancer statistics. CA: A Cancer Journal for Clinicians, 61(2), 69-90. doi:10.3322/caac. 20107
Karou, D., Dicko, M. H., Simporé, J., Yameogo, S., Sanon, S. \& Traoré, A. S. (2005). Activités antioxydantes et antibactériennes des polyphénols extraits de plantes médicinales de la pharmacopee traditionnelle du burkina faso. Maitrise des procédés en vue d'améliorer la qualité et la sécurité des aliments, utilisation des OGM, analyse des risques en agroalimentaire. ouagadougou, 8-11.

Kumar, A., Shukla, R., Singh, P., Shekhar Prasad, C. \& Kishore Dubey, N. (2008). Assessment of Thymus vulgaris L. essential oil as a safe botanical preservative against post harvest fungal infestation of food commodities. Innovative Food Science $\& 5$ Emerging Technologies, 9, 575-580. doi:10.1016/ j.ifset.2007.12.005

Leahy, S., Higgins, D., Fitzgerald, G. \& Van Sinderen, D. (2005). Getting better with bifidobacteria. Journal of Applied Microbiology, 98, 1303-15. doi:10.1111/j.13652672.2005.02600.x

Li, H.-B., Cheng, K.-W., Wong, C.-C., Fan, K.-W., Chen, F. \& Jiang, Y. (2007). Evaluation of antioxidant capacity and total phenolic content of different fractions of selected microalgae. Food Chemistry, 102, 771-776. doi:10.1016/j.foodchem.2006.06. 022

Liu, R. H. (2004). Potential synergy of phytochemicals in cancer prevention: Mechanism of action. The Journal of Nutrition, 134(12), 3479S-3485S. doi:10.1093/jn/134. $12.3479 \mathrm{~S}$

Muanda, F., Soulimani, R., Diop, B. \& Dicko, A. (2011). Study on chemical composition and biological activities of essential oil and extracts from Stevia rebaudiana Bertoni leaves. LWT - Food Science and Technology, 44, 1865-1872. doi:10.1016/j.lwt. 2010.12.002

Ouwehand, A., Isolauri, E. \& Salminen, S. (2002). The role of the intestinal microflora for the development of the immune system in early childhood. European Journal of Nutrition, 41 Suppl 1, I32-7. doi:10.1007/ s00394-002-1105-4

Park, H.-J. \& Cha, H.-C. (2003). Flavonoids from leaves and exocarps of the grape ky- 
oho. Korean Journal of Biological Sciences, 7, 327-330. doi:10.1080/12265071. 2003. 9647723

Parkin, D. M., Bray, F., Ferlay, J. \& Pisani, P. (2001). Estimating the world cancer burden: Globocan. Int J Cancer, 94, 153-156.

Pokorny, J. \& Schmidt, S. (2001). Antioxidants in food: Practical applications. Antioxidants in Foods, 331-354. doi:10.1533/ 9781855736160.4.331

Pottier, A. (1981). Flore de la tunisie. Programme Flore et Végétation Tunisiennes, Publications Scientifiques Tunisiennes, Tunis, 1, 402-405.

Razali, N., Razab, R., Junit, S. \& Abdul Aziz, A. (2008). Radical scavenging and reducing properties of extracts of cashew shoots (anacardium occidentale). Food Chemistry, 111, 38-44. doi:10.1016/j.foodchem.2008. 03.024

Rickard, A., Gilbert, P., J. High, N., E. Kolenbrander, P. \& S. Handley, P. (2003). Bacterial coaggregation: An integral process in the development of multi-species biofilms. Trends in Microbiology, 11, 94-100. doi:10. 1016/S0966-842X(02)00034-3

Rowland, I. R. (2009). The role of the gastrointestinal microbiota in colorectal cancer. Current Pharmaceutical Design, 15, 1524-7. doi:10 . 2174 / 138161209788168191

Rsaissi, N. \& Bouhache, M. (2002). La lutte chimique contre le jujubier. Transfert de technologie en agriculture, 94, 1-4.

Es-Safi, N. E., Kollmann, A., Khlifi, S. \& Ducrot, P.-H. (2007). Antioxidative effect of compounds isolated from Globularia alypum L. structure-activity relationship. $L W T$ Food Science and Technology, 40, 12461252. doi:10.1016/j.lwt.2006.08.019

Samartha, D. R., Samartha, M., Kumar, M., Soni, A., Kumar, M. \& Kumar, A. (2008). Evaluation of antioxidant and radicalscavenging activity of certain radioprotective plant extracts. Food Chemistry, 106, 868-873. doi:10.1016/j.foodchem.2007.05. 005

Schachtsiek, M., P. Hammes, W. \& Hertel, C. (2005). Characterization of lactobacillus coryniformis dsm 20001t surface protein cpf mediating coaggregation with and aggregation among pathogens. Applied and Environmental Microbiology, 70, 7078-85. doi:10.1128/AEM.70.12.7078-7085.2004

Schillinger, U., Guigas, C. \& Holzapfel, W. (2005). In vitro adherence and other properties of lactobacilli used in probiotic yoghurt-like products. International Dairy Journal, 15, 1289-1297. doi:10.1016 / j . idairyj.2004.12.008

Sirk, T., Brown, E. F., Sum, A. \& Friedman, M. (2008). Molecular dynamics study on the biophysical interactions of seven green tea catechins with lipid bilayers of cell membranes. Journal of Agricultural and Food Chemistry, 56, 7750-8. doi:10.1021/ jf8013298

Suksamrarn, S., Suwannapoch, N., Aunchai, N., Kuno, M., Ratananukul, P., Haritakun, R., ... Ruchirawat, S. (2005). Ziziphine n, o, p and q, new antiplasmodial cyclopeptide alkaloids from Ziziphus oenoplia var. brunoniana. Tetrahedron, 61, 1175-1180. doi:10. 1016/j.tet.2004.11.053

Sun, T., Powers, J. R. \& Tang, J. (2007). Evaluation of the antioxidant activity of asparagus, broccoli and their juices. Food Chemistry, 105(1), 101-106. doi:10.1016/j. foodchem.2007.03.048

Tuo, Y., Yu, H., Ai, L., Wu, Z., Guo, B. \& Chen, W. (2013). Aggregation and adhesion properties of 22 lactobacillus strains. Journal of Dairy Science, 96. doi:10.3168/jds.20136547

Vamanu, E. \& Nita, S. (2013). Antioxidant capacity and the correlation with major phenolic compounds, anthocyanin, and tocopherol content in various extracts from the wild edible boletus edulis mushroom. BioMed Research International, 2013, 313905. doi:10.1155/2013/313905

van Nimwegen, F., Penders, J., E Stobberingh, E., S Postma, D., Koppelman, G., Kerkhof, M., ... Thijs, C. (2011). Mode and place of delivery, gastrointestinal microbiota, and their influence on asthma and atopy. The Journal of Allergy and Clinical Immunology, 128, 948-55.e1. doi:10.1016/j.jaci . 2011.07.027 
Effect of Zizyphus lotus on some human pathologic bacteria $\mid 177$

Wade, D., Silveira, A., Rollins-Smith, L., Bergman, T., Silberring, J. \& Lankinen, H. (2001). Hematological and antifungal properties of temporin a and a cecropin atemporin a hybrid. Acta Biochimica Polonica, 48, 1185-9.

Wang, J., Li, J., Cao, J. \& Jiang, W. (2010). Antifungal activities of neem (Azadirachta indica) seed kernel extracts on postharvest diseases in fruits. African Journal of $M i$ crobiology Research, 4.

Warda, K., Markouk, M., Bekkouche, K., Abbad, M. L. A., Romane, A. \& Bouskraoui, M. (2009). Antibacterial evaluation of selected moroccan medicinal plants against Streptococcus pneumoniae. African Journal of Pharmacy and Pharmacology, 3(3), 101-104. Retrieved from https : / / academicjournals . org / journal / AJPP / article-abstract/35C476B33535

Wu, D., Kong, Y., Han, C., Chen, J., Hu, L., Jiang, H. \& Shen, X. (2008). D-alanine: Dalanine ligase as a new target for the flavonoids quercetin and apigenin. International Journal of Antimicrobial Agents, 32, 4216. doi:10.1016/j.ijantimicag.2008.06.010

Xiao, W., Han, L. \& Shi, B. (2008). Microwaveassisted extraction of flavonoids from radix astragali. Separation and Purification Technology, 62, 614-618. doi:10.1016/j . seppur.2008.03.025 